\title{
Diel changeover of fish assemblages in shallow sandy habitats of lowland rivers of different sizes
}

\author{
Michał Nowak ${ }^{1,3, *}$, Artur Klaczak ${ }^{1}$, Ján Koščo ${ }^{2}$, Paweł Szczerbik ${ }^{1}$, Jakub Fedorčák ${ }^{2}$, \\ Juraj Hajdú ${ }^{2,4}$ and Włodzimierz Popek ${ }^{1}$ \\ ${ }^{1}$ Department of Ichthyobiology and Fisheries, University of Agriculture in Kraków, Spiczakowa 6, 30-198 Kraków, Poland \\ 2 Department of Ecology, University of Prešov, 17. novembra 1, 08016 Prešov, Slovakia
}

Received: 17 July 2019 / Accepted: 28 September 2019

\begin{abstract}
Diel dynamics of species richness and fish abundance were studied in three lowland rivers that differed significantly in size (discharge) in to the upper Vistula River drainage system (Poland). Shallow sandy habitats at point bars were repeatedly sampled with beach seining over 24 -h periods. Species richness peaked at dusk and then decreased throughout the 24-h period in all the rivers. Overall fish abundance changed similarly in the smallest and the largest river, whereas in the mid-sized river it increased in the late afternoon hours. Some species (three gudgeon species, golden loach, and chub) were persistently nocturnal, whereas others (dace, bleak, and roach) shifted to diurnal activity in the mid-sized and large rivers. These differences in diel changes in the abundance of certain species might be explained in the context of variation in availability (i.e., proximity) of other, more heterogeneous habitats.
\end{abstract}

Keywords: 24-h cycle / lotic ecosystems / sandbars / riverine fishes / spatio-temporal variation

\begin{abstract}
Résumé - Changement circadien des assemblages de poissons dans les habitats sablonneux peu profonds des cours d'eau de plaine de différentes tailles. La dynamique de la diversité des espèces et de l'abondance des poissons a été étudiée dans trois rivières de plaine de tailles (débits) très différentes, appartenant au bassin hydrographique de la Haute Vistule (Pologne). Des habitats sablonneux peu profonds ont été échantillonnés à plusieurs reprises au moyen d'une pêche à la senne de plage sur une période de 24 heures. Dans les trois rivières, la richesse en espèces a atteint son maximum au crépuscule, puis a diminué pendant toute la période de 24 heures. Dans l'ensemble, l'abondance du poisson a changé de façon similaire dans la plus petite et la plus grande rivière, alors qu'elle a augmenté dans la rivière de taille moyenne en fin d'après-midi. Certaines espèces (trois goujons, la loche « dorée » et le chevesne) étaient constamment nocturnes, tandis que d'autres (la vandoise, l'ablette et le gardon) sont passées à une activité diurne dans la rivière de taille moyenne et grande. Ces différences dans les changements circadiens d'abondance de certaines espèces pourraient s'expliquer dans le contexte des variations dans la disponibilité (c.-à-d. la proximité) d'autres habitats plus hétérogènes.
\end{abstract}

Mots-clés : Cycle de 24 heures / écosystèmes lotiques / habitat sableux / poissons de rivière / variation spatio-temporelle

\section{Introduction}

Temporal variation in riverine fish assemblages have been known and exploited by fishers for centuries. The seasonal

\footnotetext{
*Corresponding author: mikhael. nowak@gmail.com

${ }^{3}$ Present address: Mazanów Fish Farm, Mazanów 8A, 24-340 Józefów nad Wisłą, Poland.

${ }^{4}$ Present address: State Nature Conservancy of the Slovak Republic, Tajovského 28B, 97401 Banská Bystrica, Slovakia.
}

migrations of anadromous or potamodromous species have been particularly thoroughly documented and studied (e.g., Lucas et al., 2001 and references therein). Fine-scale variation, however, has received far less attention. Nevertheless, diel differences in abundance and species richness in shallow inshore habitats are observed in various rivers in all climate zones (e.g., Copp, 2010 and references therein). In most cases, an increase in fish abundance and species richness is observed at dusk and in subsequent night hours. However, inconsistencies in published results lead to two mutually exclusive hypotheses: (i) fish generally arrive in shallow inshore habitats 
Table 1. Sampling site characteristics.

\begin{tabular}{|c|c|c|c|c|c|c|c|c|c|c|c|c|}
\hline \multirow[t]{2}{*}{ River } & \multirow[t]{2}{*}{ Site } & \multirow{2}{*}{$\begin{array}{l}\text { Latitude } \\
\left({ }^{\circ} \mathrm{N}\right)\end{array}$} & \multirow{2}{*}{$\begin{array}{l}\text { Longitude } \\
\left({ }^{\circ} \mathrm{E}\right)\end{array}$} & \multirow{2}{*}{$\begin{array}{l}\text { Elevation } \\
\text { (m a.s.1.) }\end{array}$} & \multirow{2}{*}{$\begin{array}{l}\text { Discharge } \\
\left(\mathrm{m}^{3} \mathrm{~s}^{-1}\right)\end{array}$} & \multirow{2}{*}{$\begin{array}{l}\text { River } \\
\text { width } \\
\text { (m) }\end{array}$} & \multirow{2}{*}{$\begin{array}{l}\text { Water } \\
\text { depth } \\
(\mathrm{cm})\end{array}$} & \multirow{2}{*}{$\begin{array}{l}\text { No. of } \\
\text { sampling } \\
\text { events }\end{array}$} & \multicolumn{4}{|c|}{ Water temperature $\left({ }^{\circ} \mathrm{C}\right)$} \\
\hline & & & & & & & & & Spring & Summer & Autumn & Winter \\
\hline Vistula & Łęka & 50.2827 & 20.8498 & 168 & 230.0 & 181 & $45-65$ & 7 & 16.1 & 21.5 & 7.8 & 5.1 \\
\hline Nida & Stara Rudawa & 50.4131 & 20.5792 & 174 & 22.0 & 28 & $30-80$ & 8 & 12.5 & 19.2 & 7.8 & 5.9 \\
\hline Czarna Nida & Gaj & 50.7572 & 20.5052 & 211 & 6.5 & 15 & $30-95$ & 8 & 11.3 & 21.4 & 4.8 & 4.2 \\
\hline
\end{tabular}

at dusk mainly in small rivers whereas in large ones they occupy this type of habitat during the daytime (Copp, 2010) or (ii) nocturnal increase in abundance and species richness is more conspicuous in large rivers whereas in small ones fish occupy inshore habitats throughout $24-\mathrm{h}$ periods (Janáč and Jurajda, 2013).

The validity of these hypotheses was verified by conducting a study on three rivers within a single watershed (the Vistula River drainage basin within the Baltic Sea catchment) that are direct tributaries of one another but that differ by an order of magnitude in terms of mean annual discharge.

\section{Materials and methods}

\subsection{Study area}

This study was performed in the upper Vistula River basin in Poland. With a length of $1047 \mathrm{~km}$ and a mean annual discharge at its mouth of approximately $1046 \mathrm{~m}^{3} \mathrm{~s}^{-1}$, the Vistula River is the longest river draining into the Baltic Sea. The first sampling site was located $766 \mathrm{~km}$ upstream from the river mouth in the upper course of the river. The mean annual discharge at the closest hydrological station is approximately $230 \mathrm{~m}^{3} \mathrm{~s}^{-1}$. The second sampling site was located in the Nida River, which is a left-bank tributary to the Vistula. It is a midsized lowland river $151 \mathrm{~km}$ in length with a mean annual discharge at its mouth of approximately $22 \mathrm{~m}^{3} \mathrm{~s}^{-1}$. The last sampling site was located in the Czarna Nida River, a tributary of the Nida River, which is $64-\mathrm{km}$ long, and its mean annual discharge at the confluence with the Nida is $6.5 \mathrm{~m}^{3} \mathrm{~s}^{-1}$. The three rivers differ in mean annual discharge by an order of magnitude. Basic habitat characteristics, including elevation a.s.l., mean annual discharge at the closest hydrological station, mean riverbed width, minimum and maximum water depth recorded at the sampling site, water current velocity, number of sampling events, and seasonal variation in water temperature (daily minima and maxima) are summarized in Table 1. All three sampling sites were sandy point bars formed at inner bends of river meanders (Kellerhals and Church, 1989). The sites at the Czarna Nida and the Nida rivers were in semi-natural states as these river sections have never been channelized or modified in any way. Within the stretch studied, the Vistula River was modified to accommodate navigation, which included reinforcing the outer right river bank with boulders and modifying the inner left bank with stony dikes. This was done mostly in the 1970s, and over the interceding decades, the dike basins have completely filled in with mainly sandy sediment to form a new, close-to-natural sandy shoreline.

\subsection{Fish sampling}

Samples were taken every $3 \mathrm{~h}$ over a 24 -h period. A total of 23 sampling events took place from August 2014 to March 2016 (Tab. 1). In the Czarna Nida and Nida rivers fish were collected with a $6 \times 3 \mathrm{~m}$ seine net made of knotless nylon netting with a $6 \mathrm{~mm}$ mesh bar. In the Vistula River a $15-\mathrm{m}$-long bag seine net with two 6-m wings ( $8 \mathrm{~mm}$ mesh bar) and central bag $3 \times 3 \mathrm{~m}(6 \mathrm{~mm}$ mesh bar) was used to increase sampling efficiency in the much larger, shallow habitats. The seine net was dredged by two operators approximately parallel to the shoreline and then beached at each site. The area sampled was approximately $180 \mathrm{~m}^{2}$ in the Czarna Nida, $420 \mathrm{~m}^{2}$ in the Nida, and $1200 \mathrm{~m}^{2}$ in the Vistula. The catch per unit of effort (CPUE) was the raw number of fish caught in each haul. Since the main goal of the study was to investigate diel dynamics (and not total abundance), this approach was chosen as the most robust. Sampling started 3 or $6 \mathrm{~h}$ before sunset and continued for $24 \mathrm{~h}$. All fish were identified to the species when they were held in net bags in the water close to the shore to prevent mortality. Identifications were based on the author's experience, available keys (e.g., Kottelat and Freyhof, 2007), and a reference collection held at the Department of Ichthyobiology, University of Agriculture in Kraków.

\subsection{Statistical analyses}

Diel differences in species richness and abundance of the most dominant fish species ( $>100$ specimens) were analyzed with generalized linear mixed-effects models (GLMM), with raw CPUE data and Poisson error distribution. This technique is suitable for analyzing non-normal data with random effects. Two explanatory variables were tested: time after dusk (continuous) and river (three levels: Czarna Nida, Nida, and Vistula; except for Kessler's gudgeon and golden loach, ${ }^{1}$ which were analyzed only in the Vistula River) that was a fixed effect. Season (four levels: spring, summer, fall, and winter) was set as a random effect to account for pseudoreplications. In each case, four alternative models were fitted and compared according to their AIC values: (i) null model; (ii) a single fixed effect (time after dusk); (ii) two fixed effects (time after dusk and river) without interaction; and (iv) two fixed effects (time after dusk and river) with interaction. GLMM parameters were

$\overline{{ }^{1} \text { Vernacular and scientific names of all species were listed in Table } 2 .}$ 
Table 2. Total abundance of fish species in the Czarna Nida, Nida, and Vistula rivers.

\begin{tabular}{|c|c|c|c|}
\hline \multirow[t]{2}{*}{ Species } & \multicolumn{3}{|c|}{ River } \\
\hline & Czarna Nida & Nida & Vistula \\
\hline Dace Leuciscus leuciscus (Linnaeus, 1758) & 627 & 327 & 515 \\
\hline Common gudgeon Gobio gobio (Linnaeus, 1758) & 839 & 114 & 89 \\
\hline Blake Alburnus alburnus (Linnaeus, 1758) & 198 & 243 & 425 \\
\hline Roach Rutilus rutilus (Linnaeus, 1758) & 401 & 257 & 6 \\
\hline Chub Squalius cephalus (Linnaeus, 1758) & 333 & 26 & 51 \\
\hline Whitefin gudgeon Romanogobio belingi (Slastenenko, 1934) & 0 & 63 & 238 \\
\hline Kessler's gudgeon Romanogobio kesslerii (Dybowski, 1862) & 0 & 0 & 174 \\
\hline Baltic golden loach Sabanejewia baltica (Witkowski, 1994) & 4 & 10 & 96 \\
\hline Spined loach (Cobitis sp.) & 49 & 12 & 0 \\
\hline Barbel Barbus barbus (Linnaeus, 1758) & 27 & 3 & 30 \\
\hline Nase Chondrostoma nasus (Linnaeus, 1758) & 1 & 2 & 48 \\
\hline Vimba bream Vimba vimba (Linnaeus, 1758) & 1 & 1 & 45 \\
\hline Pikeperch Sander lucioperca (Linnaeus, 1758) & 2 & 2 & 37 \\
\hline White bream Blicca bjoerkna (Linnaeus, 1758) & 0 & 14 & 16 \\
\hline Perch Perca fluviatilis (Linnaeus, 1758) & 13 & 8 & 2 \\
\hline Spirlin Alburnoides bipunctatus (Linnaeus, 1758) & 1 & 18 & 2 \\
\hline Cyprinidae larvae & 3 & 0 & 14 \\
\hline Baltic bullhead Cottus microstomu (Heckel, 1837) & 11 & 2 & 1 \\
\hline Asp Leuciscus aspius (Linnaeus, 1758) & 3 & 0 & 7 \\
\hline Ide Leuciscus idus (Linnaeus, 1758) & 7 & 0 & 2 \\
\hline Stone loach Barbatula barbatula (Linnaeus, 1758) & 1 & 2 & 1 \\
\hline Giebel carp Carassius gibelio (Bloch, 1782) & 1 & 1 & 2 \\
\hline Ruffe Gymnocephalus cernua (Linnaeus, 1758) & 2 & 0 & 2 \\
\hline Rud Scardinius erythrophthalmus (Linnaeus, 1758) & 2 & 1 & 1 \\
\hline Topmouth gudgeon Pseudorasbora parva (Temminck and Schlegel, 1846) & 0 & 0 & 3 \\
\hline Welsh Silurus glanis (Linnaeus, 1758) & 1 & 2 & 0 \\
\hline Pike Esox lucius (Linnaeus, 1758) & 1 & 1 & 0 \\
\hline Burbot Lota lota (Linnaeus, 1758) & 0 & 0 & 2 \\
\hline Ukrainian brook lamprey Eudontomyzon mariae (Berg, 1931) & 1 & 0 & 0 \\
\hline Total fish catch & 2529 & 1109 & 1809 \\
\hline Overal species richness & 24 & 21 & 25 \\
\hline
\end{tabular}

estimated using Laplace estimation. All calculations were performed with R software version 3.6.0 (R Core Team, 2019) using packages lme4 (Bates et al., 2015) and ggeffects (Lüdecke, 2018).

\section{Results}

A total of 5447 fish belonging to 29 species were caught. The fish assemblages in all three rivers were dominated by small-sized cyprinids. In the Czarna Nida River, common gudgeon predominated $(33.2 \%$ of the total fish catch) over dace $(24.8 \%)$, roach $(15.9 \%)$, chub (13.2\%), and bleak $(7.8 \%)$. Another 19 species were noted to be far less abundant. In the Nida River, dace (29.5\%), roach (23.2\%), bleak (21.9\%), and common gudgeon $(10.3 \%)$ predominated decidedly over another 17 species. In the Vistula River, dace (28.5\%) was followed by bleak (23.5\%), whitefin gudgeon (13.2\%), and Kessler's gudgeon $(9.7 \%)$, while a small number of another 20 species was also noted (Tab. 2).

Species richness peaked at dusk and then gradually decreased during the night and the following day in all three rivers (Fig. 1a). The model with two fixed effects (time after dusk and river) without any interaction between them tended to be superior to the others (Tab. 3). Not surprisingly, the amplitude of differences between the maximum species richness at sunset and the daytime minimum varied among the rivers (on average, 6.25 vs. 2.60 in the Czarna Nida, $4.87 v s .1 .67$ in the Nida, and $9.29 v s .3 .86$ in the Vistula) as did their overall species diversity $(24,21$, and 25 species, respectively).

Total fish abundance was highest at dusk, and then it decreased continually in both the smallest and the largest rivers, whereas the pattern was reversed in the mid-sized river. Fish abundance was generally much lower in the mid-sized Nida River than in either the Czarna Nida or Vistula rivers, and it increased subtly toward the late afternoon hours (Fig. 1b). This was indicated by the lowest AIC value of the model including the interaction of both fixed effects (Tab. 3).

Only eight species occurred frequently and numerously enough to allow comparative analyses of their diel dynamics among the rivers. All other species were noted either sporadically or in very low numbers, which rendered any modeling inconclusive. 

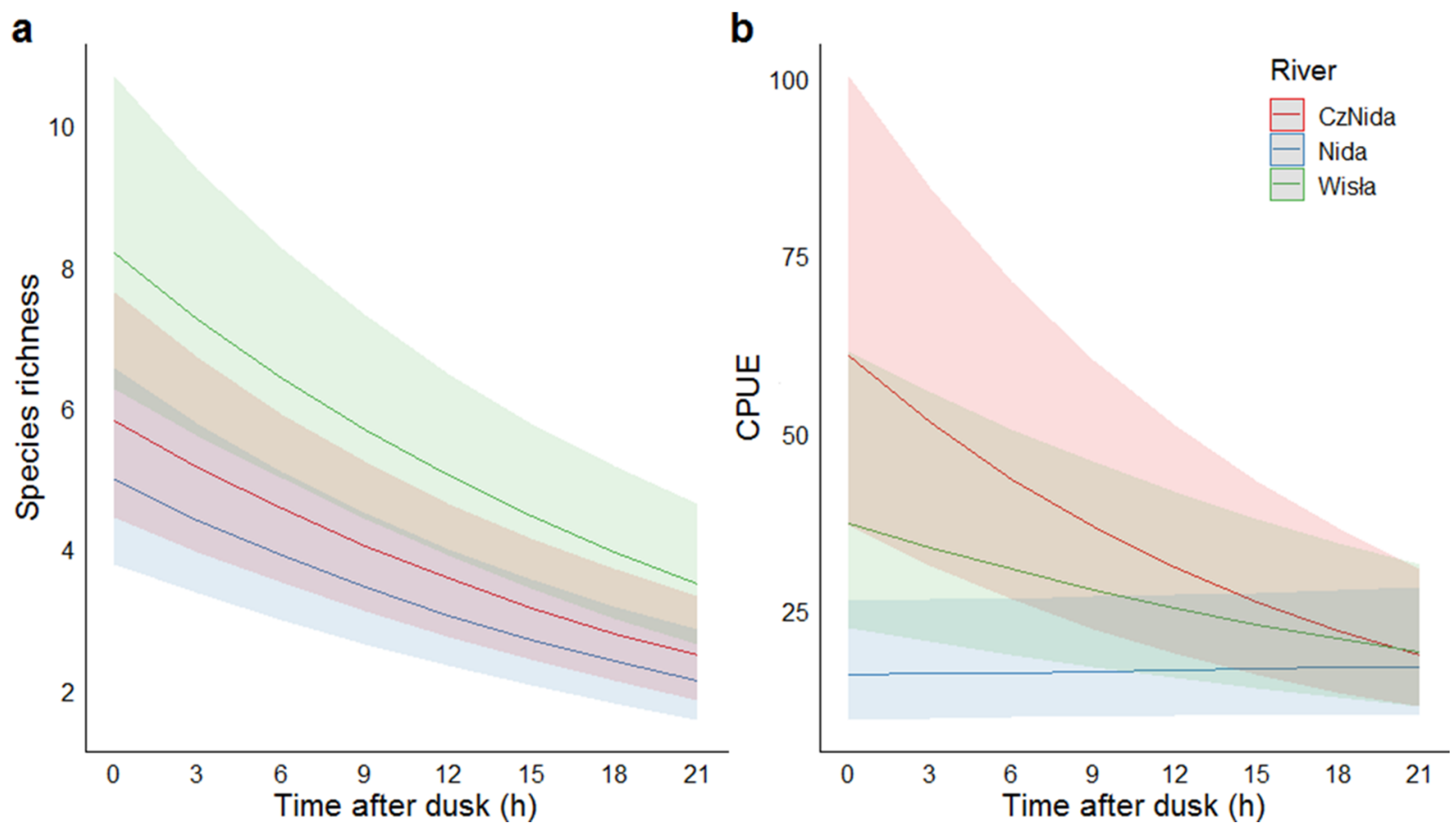

Fig. 1. GLMM plots with $95 \%$ confidence intervals (shaded area) of (a) species richness and (b) CPUE change over time in the Czarna Nida, Nida, and Vistula rivers.

Table 3. AIC values of the GLMM models analyzed.

\begin{tabular}{lllll}
\hline Variable or species & \multicolumn{3}{c}{ Model } \\
\cline { 2 - 5 } & Null (intercept) & Time & Time + River & Time $\times$ River \\
\hline Species richness & 749.6 & 696.2 & $\mathbf{6 6 6 . 4}$ & 669.8 \\
Total CPUE & 5313.8 & 4996.2 & 4449.1 & $\mathbf{4 3 2 5 . 5}$ \\
Dace & 2468.2 & 2470.1 & 2378.0 & $\mathbf{2 3 5 9 . 0}$ \\
Common gudgeon & 2643.3 & 2487.4 & 1591.6 & $\mathbf{1 5 8 5 . 9}$ \\
Bleak & 2003.6 & 1982.2 & 1880.3 & $\mathbf{1 7 5 8 . 3}$ \\
Roach & 2705.4 & 2606.6 & 2114.0 & $\mathbf{1 9 7 1 . 8}$ \\
Chub & 1407.6 & 1342.0 & 947.6 & $\mathbf{9 4 6 . 9}$ \\
Whitefin gudgeon & 809.6 & 650.2 & 552.1 & $\mathbf{5 4 6 . 4}$ \\
Kessler's gudgeon & 686.5 & 599.6 & - & - \\
Golden loach & 379.9 & 314.0 & - & - \\
\hline
\end{tabular}

Dace, the most abundant species, exhibited conspicuous variation in diel dynamics of occurrence (in the model with two fixed factors, and their interaction had the lowest AIC value; Tab. 3). In the smallest stream its abundance peaked at dusk and decreased throughout the night and the next day. In the mid-sized river dace abundance remained at a relatively constant level throughout the 24-h period. On the other hand, in the largest river its abundance increased gradually toward sunset (Fig. 2a). Similarly to dace, bleak and roach tended to be nocturnal with peak abundances at dusk in the smallest Czarna Nida River, but their abundances were diurnal with the highest concentrations in the late afternoon in both of the larger rivers (Fig. 2c and d, respectively). The abundance of roach in the Vistula River was very low. The model with interaction was superior to all the others for both of these fish species (Tab. 3).

With all three gudgeon species, i.e., the common gudgeon, whitefin gudgeon, and Kesssler's gudgeon, the pattern of diel dynamics was clear and consistent in all three rivers. Their abundance peaked at dusk and then gradually decreased over the subsequent 24-h period (Fig. 2b, f, g). In both common and whitefin gudgeons GLMM indicated significant interaction between both factors of time after dusk and river (Tab. 3) that resulted mainly from differences in CPUE values among the streams. Kessler's gudgeon occurred only in the Vistula River so analyses of its abundance were restricted to the null (intercept-only) model and the model including one fixed factor (time after dusk). The latter fit far better than the former 

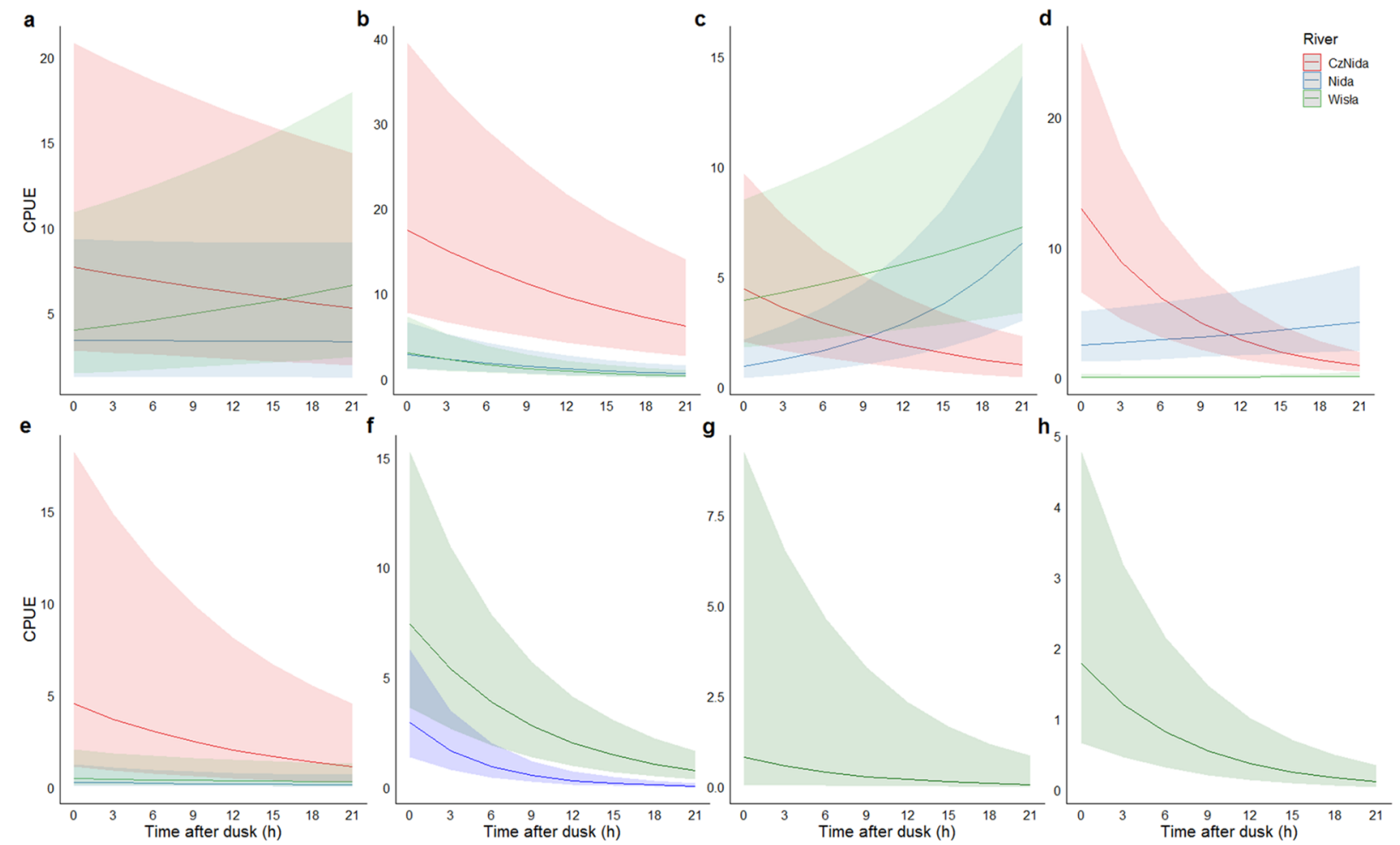

Fig. 2. GLMM plots with $95 \%$ confidence intervals (shaded area) of CPUE of fish species in the Czarna Nida, Nida and Vistula: (a) dace; (b) common gudgeon; (c) bleak; (d) roach; (e) chub; (f) whitefin gudgeon; (g) Kessler's gudgeon; (h) golden loach.

(Tab. 3). Similarly to Kessler's gudgeon, golden loach also exhibited a typically nocturnal pattern of occurrence, with abundance peaking at dusk and then decreasing sharply (Fig. 2h). This species was recorded in all three rivers; however, only in the Vistula River was its abundance high enough to permit any statistical analyses (Tab. 2). Nocturnal patterns of abundance were also noted for chub (Fig. 2e). The model with interaction between time after dusk and river had the lowest AIC (Tab. 3) that resulted from the low abundances of this species in the Nida and Vistula rivers compared to the Czarna Nida River (Tab. 2).

\section{Discussion}

Diel changeovers of fish assemblages in shallow riverine habitats are observed worldwide (e.g., Copp and Jurajda, 1993, 1999; Arrington and Winemiller, 2003; Baumgartner et al., 2008; Koščo et al., 2008; Copp, 2010; Roach and Winemiller, 2011; Janáč and Jurajda, 2013) and studies that document no differences between day and night assemblages are scarce (Czeglédi et al., 2016). This is why diel changeover is presumed to be of adaptive significance (Gliwicz and Jachner, 1992; Roach and Winemiller, 2011). Differences in the exploitation of various habitats are usually explained as tradeoffs between predator (mainly piscivorous birds) avoidance and foraging. The existence of diel dynamics, even when there are no avian predators, points to the very deep evolutionary past of this phenomenon (Gliwicz and Jachner, 1992; Mehner, 2012). Alternatively, small-sized fishes occupying shallow inshore habitats nocturnally is interpreted as avoidance of large-bodied predatory fish (Helfman, 1993; Copp and Jurajda, 1999). The dynamic trade-off between predator (either birds or fish) avoidance and foraging in shallow habitats by using subtle differences in vision in various levels of illumination between prey and predators is referred to as the "antipredator window" (Clark and Levy, 1988; Scheuerell and Schindler, 2003). According to this concept, smaller-sized fishes use the dynamic twilight zone to move inshore and offshore to negotiate predators and to reach food items.

In most cases worldwide, twilight or nocturnal increases in both abundance and species richness are recorded (e.g., Copp and Jurajda, 1993, 1999; Arrington and Winemiller, 2003; Baumgartner et al., 2008; Koščo et al., 2008; Copp, 2010; Roach and Winemiller, 2011), although some authors report the opposite scenario (Copp et al., 2005; Mastrorillo and Copp, 2005). After an extensive review of the literature, including his own numerous studies, Copp (2010) concluded that nocturnal increases in abundance and species richness occur in small rivers, whereas the pattern is reversed in large rivers. On the other hand, Janáč and Jurajda (2013) came to the opposite conclusion that fish abundance and diversity increase at night in larger rather than smaller rivers. These authors point out the importance of habitat complexity in shaping the diel dynamics of fish assemblages. Similarly to Willis et al. (2005), they contend that more structured, complex habitats might provide richer, evenly-distributed resources, which makes diel differences in fish abundance less conspicuous. On the other hand, in unstructured habitats, like sandbars in lowland rivers, resources are more scarce, 
which forces fish to engage in changeovers of occurrence or behavior over 24 -h periods.

The results of the present study indicate that in all three rivers, ranging from a stream to a large lowland river, notably more species are found in shallow sandy habitats at dusk and during the first few hours of night. However, the dynamics of fish abundance are more complex. In the smallest Czarna Nida River, the pattern of fish abundance followed that of species richness, peaking at dusk and rapidly decreasing thereafter. In the largest river, the Vistula, abundance dynamics were similar but were characterized by a lower amplitude. In the mid-sized Nida River, however, there were afternoon increases in fish abundance. These results led to the conclusion that there is no cline in diel variation of fish assemblages with regard to river size (discharge). Instead, there is an interesting shift from nocturnal to diurnal behavior in several species (dace, bleak, and roach). Five of the eight species analyzed in this study revealed similar patterns of diel changes in occurrence, which might be described as constantly nocturnal. These species (three gudgeon species, golden loach, and chub) always appeared in highest numbers at dusk and within the first few hours of darkness, after which their abundance decreased consecutively. The second group of species (dace, bleak, and roach) were nocturnal in the smallest stream, whereas in the two larger rivers their abundance either increased during the day to reach its maximum in the late afternoon, or it remained relatively constant throughout the 24 -h period.

Sampling was performed in all three rivers in the similar habitats of sandy point bars (Kellerhals and Church, 1989). These are unstructured habitats with shallow waters (depths of usually $<100 \mathrm{~cm}$ ) and plain sandy bottoms. Structural objects, such as wood debris or macrophytes, are only found in these habitats sporadically. Thus, the one different pattern of fish abundance over a 24 -h period that was found in this study cannot be explained by variations in habitat heterogeneity (Willis et al., 2005; Janáč and Jurajda, 2013), but the sandbars sampled obviously differed in size. The sandy beaches in the Czarna Nida River had an area of only approximately $200 \mathrm{~m}^{2}$. Just a few meters from the sandbar there was a deep $(>150 \mathrm{~cm})$ pool with overhanging riparian vegetation. The sandbar in the Nida River was much larger at approximately $650 \mathrm{~m}^{2}$, and there was much more distance between the sandy beach and other microhabitats. The sandbar area in the Vistula River was the largest $\left(>10,000 \mathrm{~m}^{2}\right)$ and many more heterogeneous habitats were remote $(>50 \mathrm{~m})$. According to the "inshore habitat retention" concept, such sandbars are very rich in phyto- and zooplankton (Schiemer et al., 2001), especially at night (Jack et al., 2006). Most probably in small streams, where various habitats and resources are in close proximity, most species utilize the "antipredator window" and immediately after sunset they arrive in shallow, inshore retention zones for extensive dusk feeding. In larger rivers, however, fish need to negotiate quite long distances to reach sandbars, which makes resources more scattered and competition for them more intense. This could explain why several species were preferably nocturnal in small streams whereas they switched to late afternoon hours of activity in larger rivers. If they could not reach a desired habitat fast enough at dusk, some species (especially those with better vision, like column feeders, e.g., dace or bleak) could have decided to move into it earlier as a trade-off between avian predator avoidance and foraging.
Typical bottom feeders, like gudgeons or golden loach, needed to wait longer, when lower illumination allowed them to avoid predation.

Acknowledgments. This study was supported by National Science Centre project No. 2013/09/N/NZ9/01448 (to M.N.) and Scientific Grant Agency of the Slovak Republic project VEGA 1/0918/17 (to J.K.).

\section{References}

Arrington DA, Winemiller KO. 2003. Diel changeover in sandbank fish assemblages in a neotropical floodplain river. J Fish Biol 63: 442-459.

Baumgartner LJ, Stuart IG, Zampatti BP. 2008. Determining diel variation in fish assemblages downstream of three weirs in a regulated lowland river. J Fish Biol 72: 218-232.

Bates D, Maechler M, Bolker B, Walker S. 2015. Fitting linear mixedeffects models using lme4. J Stat Soft 67: 1-48.

Clark CW, Levy DA. 1988. Diel vertical migrations by juvenile sockeye salmon and the antipredator window. Am Nat 131: 271-290.

Copp GH. 2010. Patterns of diel activity and species richness in young and small fishes of European streams: a review of 20 years of point abundance sampling by electrofishing. Fish Fisheries 11: 439-460.

Copp GH, Jurajda P. 1993. Do small riverine fish move inshore at night? J Fish Biol 43 (Suppl A): 229-241.

Copp GH, Jurajda P. 1999. Size-structured diel use of river banks by fish. Aquat Sci 61: 75-91.

Copp GH, Vranovský M, Černý J, Kováč V. 2005. Diel dynamics of young fishes and zooplankton in a lentic side-channel of the River Danube. Biologia (Bratislava) 60: 179-188.

Czeglédi I, Sály P, Takács P, Dolezsai A, Vitál Z, Nagy AS, Erős T. 2016. Do diel variations in stream fish assemblages depend on spatial positioning of the sampling sites and seasons? Acta Zool Acad Sci Hungaricae 62: 175-190.

Gliwicz ZM, Jachner A. 1992. Diel migrations of juvenile fish: a ghost of predation past or present? Arch Hydrobiol 124: 385-410.

Helfman GS. 1993. Fish behavior by day, night, and twilight, in Pitcher TJ, ed. Behaviour of teleost fishes. London: Chapman and Hall, 479-512.

Jack JD, Fang W, Thorp JH. 2006. Vertical, lateral and longitudinal movement of zooplankton in a large river. Freshwat Biol 51: $1646-1654$.

Janáč M, Jurajda P. 2013. Diel differences in 0+ fish samples: effect of river size and habitat. River Res Appl 29: 90-98.

Kellerhals R, Church M. 1989. The morphology of large rivers: characterization and management. In: Dodge DP, ed. Proceedings of the International Large River Symposium. Can Spec Publ Fish Aquat Sci 106: 31-48.

Koščo J, Pekárik L, Nowak M, Košuthová L. 2008. Diel changes in the fish assemblages in Eastern Slovakian lowland rivers. In: Kopp R, ed. Proceedings of the XI Czech ichthyological conference. Brno: MZLU, 126-131.

Kottelat M, Freyhof J. 2007. Handbook of European freshwater fishes. Cornol: Kottelat and Berlin: Freyhof.

Lucas M, Baras E, Thom TJ, Duncan A, Slavík O. 2001. Migration of freshwater fishes. Oxford: Blackwell Science, $412 \mathrm{p}$.

Lüdecke D. 2018. ggeffects: Tidy data frames of marginal effects from regression models. J Open Source Softw 3: 772.

Mastrorillo S, Copp GH. 2005. Diel dynamics of young and small fishes in a side-channel of the River Garonne, France, before and after a late-summer spate. Ann Limnol - Int J Lim 41: 15-25. 
Mehner T. 2012. Diel vertical migration of freshwater fishes proximate triggers, ultimate causes and research perspectives. Freshwat Biol 57: 1342-1359.

R Development Core Team. 2019. R: A language and environment for statistical computing. Vienna, Austria: R Foundation for Statistical Computing. https://www.R-project.org/

Roach KA, Winemiller KO. 2011. Diel turnover of assemblages of fish and shrimp on sandbanks in a temperate floodplain river. Trans Am Fish Soc 140: 84-90.
Scheuerell MD, Schindler DE. 2003. Diel vertical migration by juvenile sockeye salmon: empirical evidence for the antipredation window. Ecology 84: 1713-1720.

Schiemer F, Keckeis H, Reckendorfer W, Winkler G. 2001. The "inshore retention concept" and its significance for large river. Arch Hydrobiol 12 (Suppl.): 509-516.

Willis SC, Winemiller KO, Lopez-Fernandez H. 2005. Habitat structural complexity and morphological diversity of fish assemblages in a Neotropical floodplain river. Oecologia (Berlin) 142: 284-295.

Cite this article as: Nowak M, Klaczak A, Koščo J, Szczerbik P, Fedorčák J, Hajdú J, Popek W. 2019. Diel changeover of fish assemblages in shallow sandy habitats of lowland rivers of different sizes. Knowl. Manag. Aquat. Ecosyst., 420, 41. 